\title{
REDACTIONEEL
}

\section{Empirische rechtswetenschap: Fad, Feud or Fellowship?}

\author{
Hilke Grootelaar
}

De redactie van Recht der Werkelijkheid vroeg mij een aantal maanden geleden of $\mathrm{ik}$ als kersverse redactiesecretaris het redactioneel van het eerste nummer in 2017 wilde schrijven. Op dat moment zat de VSR-conferentie (januari 2017) met het thema Empirical legal studies: Fad, Feud or Fellowship? nog vers in mijn geheugen. Op de vrijdagochtend werd deze conferentie afgesloten met een stevige discussie over de vraag of empirisch juridisch onderzoek nu een rage ( $\mathrm{fad}$ ) of een twistpunt (feud) was. Of was het misschien oude wijn in nieuwe zakken? Vragen die centraal stonden waren: Waar hebben we het nou eigenlijk over? Hebben we het idee dat deze onderzoekstraditie groeit? En hoe verhoudt deze zich tot de 'reguliere' rechtswetenschap? Wat dat laatste ook precies mag betekenen, want daarover zijn juristen het ook nog niet eens. ${ }^{1}$

Een aantal weken eerder bezocht ik voor het eerst het nieuwe gebouw van de Hoge Raad aan het Korte Voorhout in Den Haag, waar gelijksoortige geluiden klonken. Hier vond de door de NSCR georganiseerde conferentie Empirical Legal Studies: heden en toekomst plaats in het kader van de landelijke stimuleringsactie Empirical Legal Studies. Dit door de NWO gefinancierde initiatief werd door de voorzitter van de landelijke stuurgroep, Fred Hammerstein, liefkozend 'Els' genoemd, als ware het een vriendelijke buurvrouw. Tijdens deze bijeenkomst pitchten sprekers uit zowel de wetenschap als de praktijk de stand van zaken van empirisch juridisch onderzoek in de wetenschap en het onderwijs. Wat mij vooral is bijgebleven van deze middag is de positieve sfeer die er hing rond dit thema. Het ging de goede kant op met Els en door verschillende sprekers werden de voordelen van deze verbreding van de rechtswetenschap genoemd. Zo leidt het volgens Arno Akkermans tot een breder mensbeeld en daarmee een rijker beeld van het recht; beschreef Marijke Malsch welk voordeel de rechtspraktijk kan doen met gedegen (rechtspsychologisch) empirisch onderzoek en besprak Gijs van Dijck de factoren die ten grondslag liggen aan het succes van Els. Zo dient empirisch onderzoek vooral aan te sluiten bij de belevingswereld van de juridische gemeenschap, willen juristen het belang hiervan inzien.

De vraag of juristen zich empirische onderzoeksmethoden ook daadwerkelijk zelf eigen maken, werd beantwoord door Nieke Elbers. Zij presenteerde de resultaten van haar onderzoek naar het empirische gehalte van proefschriften van $\mathrm{PhD}$-stu-

1 Ik verwijs hierbij onder meer naar de discussie die Carel Stolker (2003) heeft aangewakkerd met zijn stuk 'Ja, geléérd zijn jullie wel'. 
denten die promoveerden aan een Nederlandse rechtenfaculteit in 2015. Uit haar systematische review blijkt dat het aantal empirische onderzoeken nog klein is. Een bevinding die ik herken binnen ons eigen departement Rechtsgeleerdheid. De dominante traditie is nog steeds dat promovendi bij voorkeur Nederlandstalige monografieën schrijven. Dit heeft er volgens mij onder meer mee te maken dat veel juridische promovendi hun carrière vervolgen binnen de rechtspraktijk. Dan schrijf je liever een klassieker die bij iedere advocaat of rechter op het nachtkastje ligt dan een 'bundeltje' Engelstalige artikelen dat waarschijnlijk minder snel gelezen zal worden door ditzelfde publiek. Ook levert dit soms kritische vragen op ten aanzien van co-auteurschap: wie heeft nu precies wat gedaan? En standpunten als: de promovendus heeft het dus niet alleen geschreven. Dat is jammer. Ik ervaar juist de enorme meerwaarde van het promoveren op Engelstalige artikelen. De ervaring van een peer review-procedure met feedback van verschillende ervaren referenten is ongelofelijk leerzaam. Het leert de promovendus zowel om te gaan met stevige kritiek als samen te schrijven met een ervaren wetenschapper en het publiceren van artikelen voorafgaand aan de promotiedatum vergroot bovendien de kans dat het werk van de promovendus al tijdens het promotietraject wordt gelezen. Dit alles lijkt mij niet onbelangrijk voor jonge onderzoekers die een wetenschappelijke carrière ambiëren.

Goed, terug naar Els. Wat kunnen we nu met betrekking tot de titel van dit redactioneel concluderen?

Ondanks de opgewekte stemming die er heerst rondom het thema, proef ik toch ook bij veel collega's een gezonde dosis weerstand en terughoudendheid als het gaat over Els. 'Wat is er mis met klassiek-juridische rechtswetenschap?' 'Moet ik als privatist nu opeens tabellen gaan opnemen in mijn artikelen?' En: 'Ligt de focus niet te veel op kwantitatief onderzoek?' Soortgelijke vragen kwamen ook aan bod tijdens de discussie op de VSR-conferentie van januari.

Deze vragen hebben onder meer te maken met de Amerikaanse oorsprong van Els. Deze gaat terug tot het begin van de twintigste eeuw met de opkomst van de Legal Realists in de Verenigde Staten. Deze rechtsrealisten vonden sociaalwetenschappelijke kennis over gedrag van bijvoorbeeld rechters belangrijk. Zij worden ook wel gezien als de grondleggers van het huidige empirisch-juridisch onderzoek. ${ }^{2}$ Met Gijs van Dijck ben ik het eens dat we beter kunnen spreken van empirisch-juridisch onderzoek of empirische rechtswetenschap, in plaats van Els (hoewel het vriendelijke 'Els' in het Nederlands natuurlijk wel lekker bekt). Dit heeft alles te maken met de connotatie van Els. In de praktijk richt het NoordAmerikaanse ELS zich namelijk in belangrijke mate op statistische analyses van datasets en databases, waardoor het veel kwantitatiever lijkt te zijn dan het zogeheten Law and Society-onderzoek. ${ }^{3}$ Omdat Marijke Malsch op de VSR-conferentie terecht uitlegde dat het Nederlandse Els-initiatief gezien moet worden als een poging om juristen iets meer te laten doen met empirisch onderzoek, stel ik voor 
om te spreken van empirische rechtswetenschap of empirisch-juridisch onderzoek. Deze term doet niet alleen meer recht aan de verscheidenheid van onderzoeken die binnen deze onderzoekstraditie vallen, maar zal voor de klassiek-juridische rechtswetenschapper ook minder bedreigend overkomen.

De toenemende aandacht voor empirisch-juridisch onderzoek dwingt tot zelfreflectie van juristen. Als dit zo wezenlijk anders is dan het doen van klassiek-juridisch onderzoek, wat zegt dat dan over de onderzoeksmethodologie van deze laatste? Verschillende juristen lieten hier reeds hun licht over schijnen. ${ }^{4}$ Ook toonde Hervé Tijssen in zijn proefschrift De juridische dissertatie onder de loep aan dat rechtswetenschappers hun gebruikte methoden, ook wanneer zij beweren empirisch onderzoek te doen, in belangrijke mate impliciet, beperkt expliciet of zelfs helemaal niet verantwoorden. Er lijkt volgens hem een understanding binnen het forum te bestaan dat juridische methoden niet nader gemotiveerd hoeven te worden. ${ }^{5}$ Een positieve bijkomstigheid van de toegenomen aandacht voor empirische rechtswetenschap is mijns inziens dat juristen kritischer nadenken over de vraag hoe dit zich verhoudt tot klassieke rechtswetenschap en steeds meer gedwongen worden om consequenter en transparanter te zijn over de door hen gebruikte onderzoeksmethodologie.

Omdat er nu eenmaal weinig mensen echt houden van veranderingen, bespeur ik dus bij de klassiek-juridische rechtswetenschapper enige weerstand. Maar we moeten mijns inziens zeker niet spreken van een feud. Mensen zijn vaak geneigd te denken in of-of situaties. Of we moeten als faculteit honderdtachtig graden draaien en vol inzetten op multidisciplinair onderzoek ('Want dat is de toekomst') of we moeten als jurist blijven bij onze positiefrechtelijke leest. Ik pleit voor denken in termen van 'én-én'. Zoals Kees van den Bos in zijn oratie ter aanvaarding van zijn leerstoel 'Empirische Rechtswetenschap' terecht stelde, is er een traditie om empirisch onderzoek sterk te contrasteren met positiefrechtelijk onderzoek en normatieve wetenschap. Hij pleit ervoor om met die conflictueuze traditie te breken en stelt dat beide elkaar nodig hebben. Waar empirisch onderzoek kan helpen in de onderbouwing van normatieve beweringen, kunnen de sociale wetenschappen hun voordeel doen met de normatieve inzichten, juridische kaders en zorgvuldige analyse van teksten en documenten uitgevoerd door juristen. ${ }^{6}$

Ook is er geenszins sprake is van een fad. Hoewel de aandacht voor empirische rechtswetenschap opeens exponentieel lijkt toe te nemen, is het daadwerkelijk uitvoeren van empirische onderzoeken iets wat al veel langer gaande is binnen de juridische discipline. Iets wat ik het lezerspubliek van Recht der Werkelijkheid - een tijdschrift dat zich nota bene richt op de sociaalwetenschappelijke bestudering van het recht - natuurlijk niet hoef uit te leggen. Wel is het volgens mij zo dat de populariteit van empirische rechtswetenschap en de aandacht voor empirische methodologieën groeit. Dit zien we onder meer terug in de titels van verschil- 
lende conferenties en special issues van tijdschriften de afgelopen jaren. Dus hoewel er gevoelsmatig sprake is van een plotselinge 'rage', zou ik eerder willen spreken van het steeds zichtbaarder worden van een noodzaak.

Zoals mijn voorganger Nina Holvast in haar redactioneel van het eerste nummer in 2016 al constateerde, is er namelijk vanuit de beroepspraktijk een groeiende behoefte aan juristen die niet alleen de positiefrechtelijke wet kennen, maar die ook bevindingen uit empirisch onderzoek op waarde kunnen schatten en kunnen integreren in de uitoefening van hun professie. Ook pleitte ik eerder met Kees van den Bos voor een zinvolle combinatie van klassiek-juridisch onderzoek met empirisch gedragswetenschappelijk onderzoek voor rechtenstudenten. Omdat er allerlei aannames over het menselijk gedrag in juridisch denken besloten liggen, kan empirisch onderzoek helpen om deze aannames op houdbaarheid te toetsen. Het is niet alleen belangrijk voor rechtenstudenten wat mensen denken en doen, maar ook hoe en waarom zij dat doen. ${ }^{7}$ Ius Commune, de onderzoeksschool voor Nederlandse en Vlaamse promovendi, is momenteel bezig met de ontwikkeling van een empirische tak en de meeste Nederlandse rechtenfaculteiten hebben inmiddels een leerstoel voor de empirische bestudering van het recht. ${ }^{8}$

Geen fad, geen feud, is het antwoord dan gelegen in fellowship? Mijn antwoord klinkt volmondig: ja! Empirische rechtswetenschap is het gebroederlijk optrekken als fellows van juristen, interdisciplinaire wetenschappers en wetenschappers uit andere bloedgroepen. Alleen waar het moet, samen waar het kan. Interdisciplinair onderzoek moet zeker niet top-down worden opgelegd door universiteitsbesturen of landelijke wetenschapsorganisaties. Echter, her en der een spreekwoordelijk duwtje in de rug, door middel van een subsidie zoals de NWO die ter beschikking heeft gesteld voor de stimulering van Els, is meer dan welkom.

Een mooi voorbeeld van het kameraadschap tussen juristen en andere wetenschappers was de workshop 'Trusting (and) the Law' georganiseerd door Ingrid van Biezen, Willem van Boom, Jan de Keijser, Wim Voermans en Geerten Waling van de Universiteit Leiden. Een week lang (!) boog ik mij in januari samen met een internationale groep psychologen, politicologen, sociologen, economen, criminologen en juristen over vragen als wat is vertrouwen, hoe onderscheiden we vertrouwen van andere concepten en hoe vergroten we het vertrouwen in onze instituties? Doel van deze intensieve workshop was om samen een innovatieve onderzoeksagenda te maken die zou kunnen dienen als startschot voor meer interdisciplinair onderzoek naar de oorsprong van vertrouwen en de manier waarop dat interacteert met het recht. Ik heb deze dagen als bijzonder vruchtbaar ervaren. Dat had onder meer te maken met de open houding van de verschillende deelne-

$7 \quad$ Grootelaar \& Van den Bos 2015, p. 860.

8 Naast de klassieke leerstoelen 'Rechtssociologie' aan verschillende universiteiten, bekleedt Frans Leeuw bijvoorbeeld de leerstoel 'Law, Public Policy and Social Science Research' aan Maastricht University, bekleedt Bert Marseille de leerstoel 'Bestuurskunde, i.h.b. de empirische bestudering van het bestuursrecht', bekleedt Kees van den Bos de leerstoel 'Empirische Rechtswetenschap' en heeft hoogleraar burgerlijk recht Willem van Boom naar eigen zeggen een grote belangstelling voor multidisciplinair onderzoek naar de werking van het privaatrecht in 'de echte wereld'. 
mers. Het doel was niet om elkaar te overtuigen van elkaars discipline en gebruikte definities. Vanzelfsprekend doen politicologen op een andere manier onderzoek naar vertrouwen dan juristen. Sterker nog, juristen veronderstellen vaak dat vertrouwen bestaat en bouwen vervolgens hun redenering op deze aanname. De inzichten die de verschillende wetenschappers over het voetlicht brachten, waren zonder meer verrijkend. Ik heb van meerdere deelnemers gehoord dat zij aan het einde van de week vol inspiratie terug naar hun werkplek gingen.

De verschillende auteurs die bijdragen aan dit nummer van Recht der Werkelijkheid is empirische rechtswetenschap ook niet vreemd. Van Duijneveldt, Wijga en Van Reisen maken gebruik van een zogenoemde mixed-method approach: zij maken een kwantitatieve analyse van de relatie tussen werkdruk en werklast op basis van de resultaten van een medewerkerswaarderingsonderzoek onder 975 rechters en officieren van justitie. Daarnaast verrichten zij een kwalitatief onderzoek naar verklarende factoren voor werkdruk in de rechtspraak. Ter Voert en Klein Haarhuis onderzoeken in hun bijdrage de empirische vraag in hoeverre burgers met problemen gebruikmaken van rechtshulp; in hoeverre dit gebruik samenhangt met kenmerken als inkomensniveau en welke redenen burgers zelf geven voor het niet gebruiken van rechtshulp. Zij analyseerden gegevens over 1.928 respondenten, die zij met behulp van twee verschillende enquêtes verzamelden. Het artikel van Bantema laat zien hoe tevreden uitkeringsgerechtigden zijn met de wijze waarop het contact met uitkeringsinstanties verloopt. Daarbij kijkt hij niet alleen naar de gewenste wijze van contact, maar is er ook aandacht voor de manier waarop het contact in de praktijk daadwerkelijk verloopt. Harde kwantitatieve data wisselt Bantema af met illustratieve kwalitatieve citaten. Met zijn bijdrage voor de rubriek Werk in Uitvoering laat Van Wijk zien welke belangrijke empirische vragen onbeantwoord blijven door andere auteurs. Met zijn empirische onderzoek in de lokale prostitutiesector laat Van Wijk zien of actoren verschillende morele opvattingen ten aanzien van prostitutie hanteren en hoe deze het handelen en sturen beïnvloeden. Al deze bijdragen laten stuk voor stuk zien wat de meerwaarde van empirisch onderzoek voor zowel het juridische als theoretische domein kan zijn.

\section{Referenties}

Bos, K. van den, Kijken naar het recht (oratie Utrecht), Utrecht: Universiteit Utrecht 2014. Dijck, G. van, 'Naar een succesformule voor empirisch-juridisch onderzoek', Justitiële verkenningen (thema: Empirisch-juridisch onderzoek), 2016, 42, p. 29-42.

Leeuw, F.L., 'Amerikaans rechtsrealisme en empirisch-juridisch onderzoek', Justitiële verkenningen (thema: Empirisch-juridisch onderzoek), 2016, 42, p. 9-28.

Grootelaar, H.A.M. \& K. van den Bos, 'Denken + meten = weten', Ars Aequi, 2015, 64, p. 858-860.

Stolker, C., 'Ja, geléérd zijn jullie wel! Over de status van de rechtswetenschap', Nederlands Juristenblad, 2003, 15, p. 766-778.

Smits, J., Omstreden rechtswetenschap. Over aard, methode en organisatie van de juridische discipline, Den Haag: Boom Juridische Uitgevers 2009. 
Hilke Grootelaar

Taekema, S. \& B. van Klink, 'Dwarsverbanden. Interdisciplinair onderzoek in de rechtswetenschap', Nederlands Juristenblad, 2009, p. 2559-2566.

Thijssen, H., De juridische dissertatie onder de loep, Den Haag: Boom Juridische Uitgevers 2009.

Westerman, P.C. \& M.H. Wissink, 'Rechtsgeleerdheid als rechtswetenschap', Nederlands Juristenblad, 2008, 9, p. 503-507. 